\title{
Michael Zimmermann/Katharina Kaiser (Konstanz) Refining current insights into the wh-in-situ interrogative construction in French: the case of Contemporary Hexagonal French
}

\begin{abstract}
This paper addresses the debate on the existence of specifically syntactic restrictions on one of a larger set of structures available in Modern French for information-requesting questions with a non-subject $w h$-phrase: the so-called $w h$ in-situ interrogative construction, in which the wh-phrase occurs in post-verbal position. From a comprehensive investigation of the applicability of such restrictions that is based on a large number of instances of the $w h$-in-situ interrogative construction from a specially designed large-scale corpus instantiating the present-day French of Metropolitan France, the paper essentially establishes that, in this variety, a fair number of these restrictions do not hold. Additionally, the paper explores the existence of morphological as well as syntactic restrictions not yet thoroughly explored in the literature and, fundamentally, uncovers that, in the variety looked into, various issues pertaining to the verb (tense, mood, passive voice, verb class, non-finite clausal complements) do not bear on the felicity of the wh-in-situ interrogative construction, while a restriction possibly holds that relates to the specificity of the subject.
\end{abstract}

\section{Introduction ${ }^{1}$}

Present-day Metropolitan French, or Contemporary Hexagonal French (in keeping with the common designation of Metropolitan France as l'Hexagone 'the Hexagon', owing to the hexagonal shape of its territory), is typologically unique in displaying, in its various registers, a wide range of syntactic structures regarding in particular root information-requesting questions with a non-subject $w h$-phrase.

1 Part of this work was funded through the research project P2 'Word Order Variation in WhQuestions: Evidence from Romance', financed by the Deutsche Forschungsgemeinschaft (German Research Foundation) as part of the Research Unit 2111 'Questions at the Interfaces', set up at the University of Konstanz. For helpful comments on an earlier version of this paper, many thanks are due to the audience of the workshop 'Recent Issues in the Syntax of Questions', University of Konstanz, 8-10 October 2018, well as to Georg A. Kaiser, Anika Lloyd-Smith, George Walkden, two anonymous reviewers, and the editors. The usual disclaimers apply. 
Abstracting away from the numerous structures additionally obtaining with clefting (by means of (one of the allomorphs of) c'est ... que 'it is ... who/which'), Contemporary Hexagonal French has in principle no less than five basic constructions for a direct non-subject $w h$-interrogative, viz., constructions with

(i) a sentence-initial wh-phrase and V(erb)-S(ubject) order ((1a-a')),

(ii) a sentence-initial $w h$-phrase and $\mathrm{S}_{\text {non-clitic }}-\mathrm{V}$ - $\mathrm{S}_{\text {clitic }}$ order ((1b)),

(iii) a sentence-initial $w h$-phrase followed by the interrogative particle est-ce que and S-V order ((1c)),

(iv) a sentence-initial $w h$-phrase and S-V order ((1d)),

(v) a sentence-final $w h$-phrase and S-V order ((1e)).

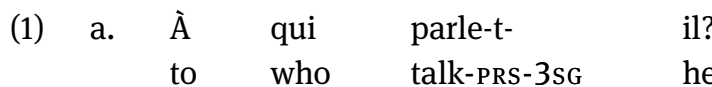

$\begin{array}{lllll}\text { a'. } & \text { À qui } & \text { parle } & \text { Jean? } \\ & \text { to } & \text { who } & \text { talk-PRs-3sg } & \text { Jean }\end{array}$

b. À qui Jean parle-t- il?

to who Jean talk-PRs-3sg he

c. ¿̀ qui est-ce qu'/e il / Jean parle?

to who $Q$ he Jean talk-PRS-3sG

$\begin{array}{lllllll}\text { d. À qui } & \text { il / Jean } & \text { parle? } \\ & \text { to } & \text { who } & \text { he } & \text { Jean } & \text { talk-PRs-3sG }\end{array}$

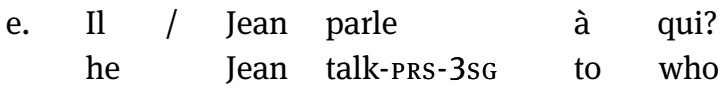

'To whom does he/Jean talk?'

The last two decades have seen an increasingly fierce debate on the particulars of the $w h$-interrogative construction illustrated in (1e). This construction is typically encountered in colloquial spontaneous speech (e.g. Valdman 1968; Behnstedt 1973; Söll 1985) and commonly referred to as ' $w h$-in-situ' in generative theorizing, as the wh-phrase here usually occurs in the very position in which, in a declarative clause, its corresponding counterpart would show up under conditions of neutral stress and intonation - rather than in some position in the left periphery of the clause, conceived of as 'wh-ex-situ'. Specifically, many claims have been put forth that are based on the view that the $w h$-in-situ interrogative construction 
in Modern French is governed by an altogether large set of restrictions pertaining essentially to the level of syntax. This view, however, has not gone unchallenged and has actually been contested regarding several of these restrictions.

Given such controversy, which appears, at least to some extent, to result from the general failure of the researchers involved to designate the respective diatopic variety of French investigated ${ }^{2}$, as well as the disregard so far for various factors that might conceivably be likewise relevant, the aim of this paper is threefold. First, the paper compiles the numerous claims encountered in the literature with respect to the availability of the wh-in-situ interrogative construction in Modern French, with a focus on those concerning syntax (Section 2). Second, on the basis of a specially designed large-scale corpus, which is limited both temporally and geographically (Section 3), the paper puts to test each of the claims gathered earlier on with regard to their applicability to Contemporary Hexagonal French (Section 4). Third, the paper investigates the possible relevance of further factors that have not yet been systematically explored in the literature and that might possibly bear on the availability of the wh-in-situ interrogative construction in the variety at issue (Section 5). From such thorough investigation the paper concludes that, in the wh-in-situ interrogative construction in the present-day French of Metropolitan France, various putative as well as conceivable chiefly syntactic restrictions do not hold, while there possibly exists an additional restriction that relates to the specificity of the subject (Section 6).

\section{A synopsis of putative restrictions on the wh-in-situ interrogative construction in Modern French}

In this section, we present the numerous claims found in the literature regarding the existence of restrictions on the interrogative construction with a non-subject

2 Cf. e.g. Mathieu (2009, 66): "La variété du français à laquelle se réfèrent Chang (1997), Boeckx (1999), Cheng et Rooryck (2000) et Zubizarreta et Vergnaud (2001) reste donc à être clairement définie. D'autant plus que de nombreuses questions considérées dans la littérature comme agrammaticales sont en fait parfaitement grammaticales aussi bien en français laurentien qu'en français de France.” [Translation [MZ/KK]: 'The variety of French to which Chang (1997), Boeckx (1999), Cheng/Rooryck (2000), and Zubizarreta/Vergnaud (2001) refer thus remains to be clearly specified. And this all the more so as many questions which are considered ungrammatical in the literature are in fact perfectly grammatical in both Lawrencian French and in the French of France.'] 
in-situ wh-phrase in today's French, focusing primarily on syntactic issues ${ }^{3}$. It must be stressed here that several of these claims have not gone unchallenged, a state of affairs that we take into account by giving pertinent references at the relevant points of discussion. Also, we will discuss only those issues which appear somewhat unexpected under the (possibly naive) null hypothesis that the wh-in-situ interrogative construction constitutes a full-fledged (syntactic) variant of the various wh-ex-situ interrogative constructions encountered in the diverse varieties and registers of the French language ${ }^{4}$.

\subsection{Modals}

The wh-in-situ interrogative construction has been argued to be not possible with modals ((2)) (Chang 1997; Cheng/Rooryck 2000 pace Starke 2001, 24; Etxepare/ Uribe-Etxebarria 2005; Adli 2006; Poletto/Pollock 2009; Baunaz 2011, 43f.).

$\begin{array}{llll}\text { (2) }{ }^{\star} \text { Il } & \text { peut } & \text { rencontrer } & \text { qui? (Chang 1997, 19) } \\ \text { he } & \text { can-PRS-3sG } & \text { meet-INF } & \text { who }\end{array}$

3 In some work, several such presumed restrictions are correlated and attributed to a particular property or condition obtaining at a given level of grammar. For instance, the supposed infelicity of negative elements, quantifiers quantifying at a distance, and modification by par exemple 'for example' (cf. Sections 2.2, 2.5, and 2.7) has been argued to follow from the contrastive focus interpretation of the $w h$-in-situ interrogative construction and, thus, to relate to the interface between LF and the semantic component (Zubizarreta 2003). Likewise, the alleged inappropriateness of negative elements, universally quantified elements preceding the wh-phrase, focus markers, long extraction contexts, non-finite embedded clauses with a complementizer, and finite embedded clauses depending on a root interrogative verb (cf. Sections 2.2, 2.4, 2.6, 2.14, 2.15, and 2.16) has been claimed to result from intervention/weak island effects induced by scopal phrases in A'-positions at the level of syntax (Mathieu 1999). Given, however, the divergence in the number of putative restrictions captured in each such work, the fundamentally different analyses put forth, the dispute on the validity of several of the restrictions appealed to (cf. the ensuing discussion), the disregard of a great many other assumed restrictions, and, essentially, the empirical orientation of this paper, the presentation of the presumed restrictions will be in the form of a list.

4 Cf. Cheng/Rooryck (2000) and Adli (2006) for discussion on the ungrammaticality of the wh-insitu interrogative construction in relative clauses, likewise ungrammatical with $w h$-ex-situ interrogative constructions. 


\subsection{Negative elements}

The $w h$-in-situ interrogative construction has furthermore been considered infelicitous with negative adverbs - e.g. pas 'not' - in general ((3)) (Chang 1997; Bošković 1998; Mathieu 1999, 2002, 2004, 2009; Cheng/Rooryck 2000; Zuckerman/Hulk 2001; Zubizarreta 2003; Shlonsky 2012 pace Baunaz 2005; Etxepare/ Uribe-Etxebarria 2005; Adli 2006; Poletto/Pollock 2009) or solely when the $w h$ phrase is an adjunct (Starke 2001, 23f.).

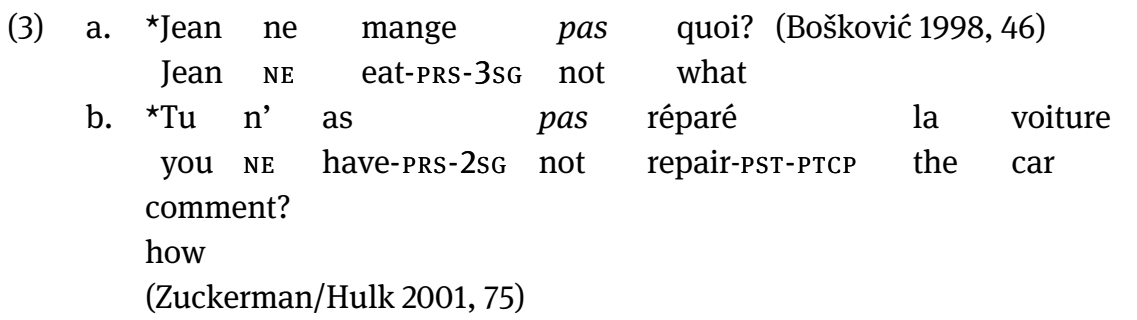

Likewise, it has been stated that the wh-in-situ interrogative construction is not appropriate with negative arguments such as personne 'nobody' ((4)) (Zubizarreta 2003).
(4) *Pierre n’ a présenté personne à qui?
Pierre NE have-PRS-3SG introduce-PST-PTCP nobody to who (Zubizarreta 2003, 364)

The wh-in-situ interrogative construction has additionally been taken as nonavailable with negative adjectives like aucun 'any' ((5)) (Zubizarreta 2003).

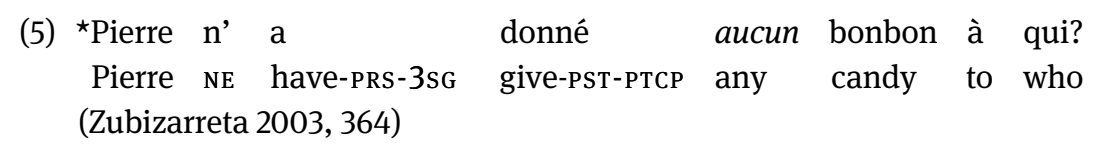

\subsection{Non-presupposed situations}

Besides, it has been stated that the wh-in-situ interrogative construction is dubious or even illicit in a non-presupposed situation and, therefore, does not allow for answers with negative elements such as rien 'nothing' and personne 'nobody' ((6)) (Coveney 1989; Chang 1997; Boeckx 1999; Cheng/Rooryck 2000; Ambar/Veloso 2001; Boeckx/Stateva/Stepanov 2001; Zubizarreta 2003 pace Obe- 
nauer 1994; Starke 2001, 52; Baunaz 2011, 52; Baunaz/Patin 2011; Hamlaoui 2011; Oiry 2011; Shlonsky 2012).

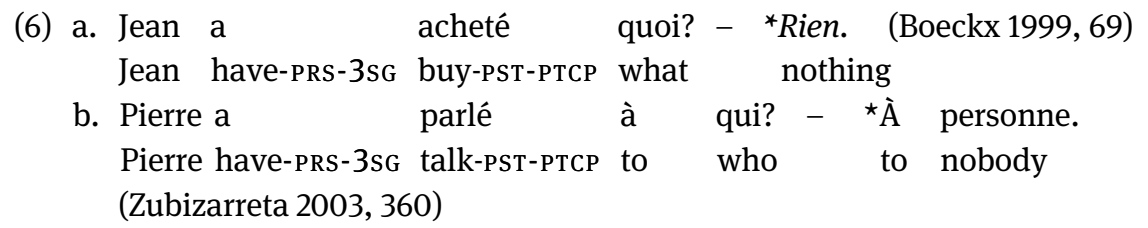

\subsection{Universally quantified elements preceding the wh-phrase}

The wh-in-situ interrogative construction has moreover been claimed to be dubious, if not excluded, with universally quantified elements preceding the whphrase, thus precluding the occurrence of universal quantifiers like tous 'all' ((7)) as well as of universal quantificational adverbs such as toujours 'always' ((8)) (Chang 1997; Cheng/Rooryck 2000; Etxepare/Uribe-Etxebarria 2005 pace Zubizarreta 2003; Baunaz 2005; Adli 2006; Poletto/Pollock 2009).

(7) ${ }^{*}$ Tous les étudiants ont rencontré qui? (Chang 1997, 17) all the students have-PRS-3PL meet-PST-PTCP who

(8) ${ }^{\star}$ Il admire toujours qui? (Chang 1997, 19) he admire-PRs-3sg always who

\subsection{Quantifiers quantifying at a distance}

In addition, it has been affirmed that the wh-in-situ interrogative construction results in ungrammaticality with quantifiers such as beaucoup 'many' in cases of so-called quantification at a distance ((9)) (Zubizarreta 2003), in which the quantifier is non-adjacent to the indefinite nominal.

$\begin{array}{llll}\text { (9) }{ }^{\star} \text { Pierre a } & \text { beaucoup } & \text { donné } & \text { de livres à qui? } \\ \text { Pierre have-PRS-3sG many } & \text { give-PST-PTCP of books to who } \\ \text { (Zubizarreta 2003,363) } & & & \end{array}$




\subsection{Focus markers}

It has moreover been contended that the wh-in-situ interrogative construction is impossible with focus markers like seulement 'only' and même 'even' ((10)) (Mathieu 1999).

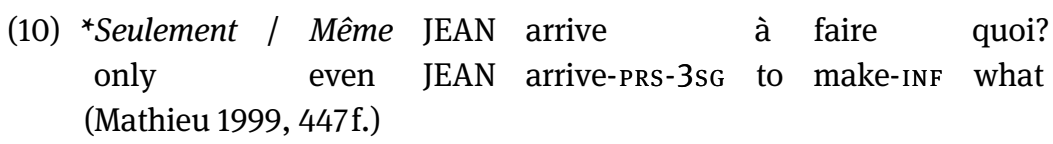

\subsection{Non-exhaustivity}

Besides, the wh-in-situ interrogative construction has been asserted to be unavailable with non-exhaustivity, thus barring modification by par exemple 'for example’ ((11)) (Zubizarreta 2003 pace Hamlaoui 2011).

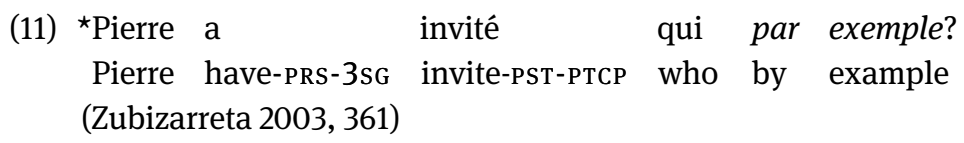

\subsection{Wh-phrases being the complement of specific DPs}

The wh-in-situ interrogative construction has likewise been considered inappropriate with a wh-phrase that is the complement of a DP with specific reference ((12)) (Starke 2001, 25).
(12) ${ }^{\star} \mathrm{Tu}$ aimerais avoir cette / ma photo de qui? you like-cond-2sg have-InF this my picture of who (Starke 2001, 25)

\subsection{Set expressions}

Additionally, it has been maintained that the wh-in-situ interrogative construction is not truly felicitous with set expressions such as How is ... ? and What's the matter? ((13)) (Obenauer 1994; Coveney 1995). 
(13) a. ??Tu vas comment? (Obenauer 1994, 321) you go-PRS-2sG how

$\begin{array}{clll}\text { b. }{ }^{*}(I l) & y & a & \text { quoi? } \\ \text { it } & \text { there } & \text { have-PRS-3SG } & \text { what }\end{array}$

\subsection{Adjunct wh-phrases}

The $w h$-in-situ interrogative construction has again been considered dubious, if not illicit, when the wh-phrase is an adjunct ((14)) (Mathieu 2004) or only when it is an adjunct that occurs clause-finally, following an object ((15)) (Mathieu 2016) or solely when it constitutes pourquoi 'why' ((16)) (Coveney 1995; Zuckerman/ Hulk 2001; Mathieu 2004; Etxepare/Uribe-Etxebarria 2005; Bayer 2006).

(14) ??Tu as vu un piano où? (Mathieu 2004, 1118) you have-PRS-2SG see-PST-PTCP a piano where

(15) ??Il est arrivé à la fête quand? (Mathieu 2016, 274) he be-PRS-3Sg arrive-PST-PTCP at the party when

(16) ${ }^{\star} \mathrm{Il}$ est parti pourquoi? (Zuckerman/Hulk 2001, 75) he be-PRS-3sg leave-PST-PTCP why

\subsection{QUEL in predicative contexts}

Also, it has been affirmed that the wh-in-situ interrogative construction is not possible in predicative contexts with (one of the allomorphs of) the wh-pronominal quel 'which one' ((17)) (Coveney 1995).

(17) *Les auteurs que vous aimez sont quels? the authors who you like-PRS-2PL be-PRS-3PL which.ones (Coveney 1995, 152)

\subsection{Wh-the hell-phrases}

Furthermore, the $w h$-in-situ interrogative construction has been claimed to be unavailable with a wh-the hell-phrase ((18)) (Obenauer 1994; Mathieu 2004). 
$\begin{array}{lll}\text { (18) }{ }^{\star} \text { Il parle } & \text { de quoi diable? (Obenauer 1994, 300) } \\ \text { he } & \text { speak-PRS-3sG } & \text { of what devil }\end{array}$

\subsection{Single full DP subject}

In addition, it has been contended that the wh-in-situ interrogative construction is at least dubious with a full DP subject that is not doubled by a co-referential clitic subject pronoun ((19)) (Mathieu 2016).

(19)

??Jean-François et Marie-Catherine ont cassé quoi? Jean-François and Marie-Catherine have-PRS-3PL break-PST-PTCP what (Mathieu 2016, 275)

\subsection{Long extraction contexts}

Besides, the wh-in-situ interrogative construction has been considered not felicitous either generally in the context of what with wh-ex-situ interrogative constructions is commonly referred to as long wh-extraction ((20)) (Bošković 1998; Boeckx 1999; Mathieu 1999; Cheng/Rooryck 2000 pace Pollock 1998, 189; Boeckx/Stateva/Stepanov 2001; Starke 2001, 22; Etxepare/Uribe-Etxebarria 2005; Adli 2006; Poletto/Pollock 2009; Shlonsky 2012; Bayer/Cheng 2017) or only when the root lexical verb is non-factive ((21)) (Boeckx/Stateva/Stepanov 2001).

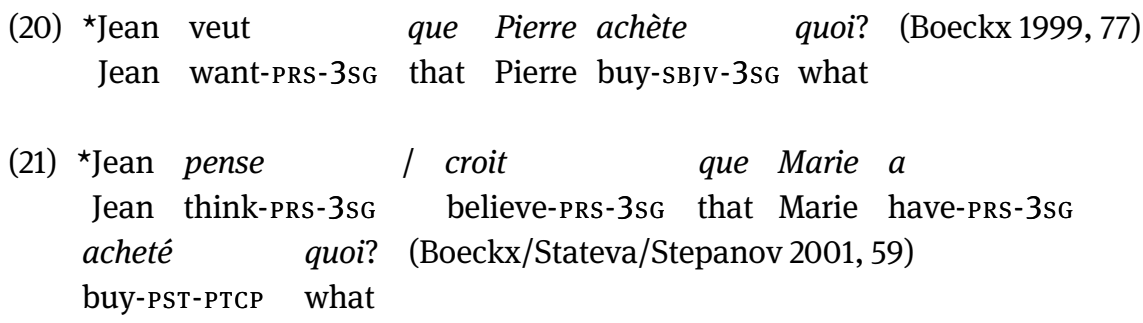

\subsection{Non-finite embedded clauses with a complementizer}

Also, it has been claimed that the $w h$-in-situ interrogative construction is impossible in a non-finite embedded clause with an infinitival complementizer ((22)) (Mathieu 1999 pace Baunaz 2005). 

(22) *Jean a décidé de faire quoi?
Jean have-PRS-3sg decide-PST-PTCP of make-INF what (Mathieu 1999, 446)

\subsection{Finite embedded clauses depending on a root interrogative verb}

Finally, the wh-in-situ interrogative construction has been taken as not felicitous when indirect, i.e. in a finite embedded clause depending on a root interrogative verb, and this irrespective of the occurrence of a complementizer ((23)) (Bošković 1998, 2000; Mathieu 1999; Cheng/Rooryck 2000; Munaro/Poletto/Pollock 2001; Zuckerman/Hulk 2001; Uribe-Etxebarria 2002; Cheng 2003; Adli 2006; Shlonsky 2012 pace Boeckx/Stateva/Stepanov 2001; Baunaz 2005).
a. *Pierre a demandé tu as vu
Pierre have-PRS-3SG ask-PST-PTCP you have-PRS-2sG see-PST-PTCP qui? (Bošković 1998, 44) who
b. *Je me demande que / si Jean a acheté I REFL ask-PRS-1SG that if Jean have-PRS-3SG buy-PST-PTCP quoi? (Cheng/Rooryck 2000, 13) what

After this succinct presentation of the fair number of - at times (highly) contentious - claims regarding the existence of basically syntactic restrictions on the interrogative construction with a non-subject in-situ wh-phrase in Modern French, we will next lay out the details of the selection of an appropriate data basis for the subsequent investigation of the applicability of these restrictions in a particular diatopic variety of the language.

\section{A large-scale corpus of the wh-in-situ interrogative construction in Contemporary Hexagonal French}

As noted in Section 1, we deem essential that an investigation of putative restrictions on the $w h$-in-situ interrogative construction in French take into due consideration the possibility of geographic variation. In accordance with this view and 
given limitations of various sorts, this paper tackles one specific diatopic variety, viz., the French of Metropolitan France ${ }^{5}$.

To assess the applicability of the numerous restrictions outlined in the previous section to the $w h$-in-situ interrogative construction in this variety, an appropriate data basis was needed. In the light of the rare occurrence of interrogatives in natural speech in general (e.g. Lipski 1977; D'Introno 2000; Martínez-Sanz 2011; Peralta Céspedes 2017), we decided to turn to a procedure that is well-known from research on earlier stages of a language for which written sources only are available: the consideration of colloquially spontaneously conceived speech from literary prose writing, in which interrogatives are actually recurrent ${ }^{6}$. Given the non-spontaneous, reflected language inherent to literary writing per se, such a procedure also has the merit of minimizing to the greatest possible extent the likelihood of the occurrence of performance errors, syntactically incomplete utterances as well as syntactic anacolutha. Yet, as with any kind of research that is corpus-based, the present procedure has a major shortcoming: whenever a structure is absent in the underlying corpus, no firm conclusions can be drawn with respect to its grammaticality, given that such absence may be due to chance, rather than infelicity. In an effort not to have a great many relevant structures purely accidentally absent, we ensured that the pertinent data come from a large-scale corpus and, fundamentally, are large in number.

5 Note that, its vast territory notwithstanding, it is generally acknowledged that the present-day French of Metropolitan France constitutes a single diatopic variety, particularly regarding the realm of syntax, while lexical as well as phonological differences are more profuse on the regional level (e.g. Koch/Oesterreicher ${ }^{2} 2011$; Kremnitz 2015; cf. also footnote 2). This fair homogeneity is usually deemed the outcome of the continuous suppression and eventual partial extinction of all other diatopic varieties by that of Ile-de-France (the so-called françois), selected as the standard in the wake of the fixation of the royal court in Paris in the 12th century and the concomitantly initiated process of political, economic as well as cultural centralization.

6 The recourse to colloquially spontaneously conceived character speech, as presently advanced, does of course not imply that such speech constitutes a true to life representation of colloquial spontaneous natural speech. In particular - and as pointed out by two reviewers - character speech often tends to be either deprived of many of the universal as well as idiosyncratic traits from different fields of grammar that typically occur in natural speech, or, on the contrary, overwrought with one or several such traits. This likewise pertains to particular constructions, as is currently the case with interrogatives. Still, what is pertinent first and foremost is that, albeit to a certain extent only, colloquially spontaneously conceived character speech does grant access to specific traits and/or constructions from colloquial spontaneous natural speech. As presently, only one particular construction is of major interest, character speech undoubtedly represents a suitable source to exploit. 
In accordance with the preceding discussion, we chose Zimmermann's (2018a) A Corpus of WH-in-Situ Interrogatives from Contemporary Hexagonal French Literary Prose Writing as an empirical basis for subsequent investigation. This corpus comprises 1,902 instances of the $w h$-in-situ interrogative construction established in 46 pieces of literary prose writing ( 45 novels and one collection of short stories) featuring a fair amount of character speech conceived of as colloquial spontaneous language. The writings, which stretch over a total of 19,098 book pages, stem from 27 mostly renowned authors, who are all native speakers of Hexagonal French, and had first been published in the period from 1995 to 2018, with the vast majority in recent years. In the context of the extraction of relevant instances, particular care had been taken to disregard four constructions that are identical from a descriptive point of view, yet different in nature ${ }^{7}$ : (i) $w h-$ echo questions, which are not genuinely information-requesting, in that their raison d'être principally relates to improper hearing/understanding or incredulity, and which, consequently, echo, or repeat, part of the usually directly preceding discourse, while expressing the improperly heard/understood or dubious non-subject element(s) in terms of a wh-phrase that is, essentially, consistently in-situ ((24)); (ii) yes/no-interrogatives with an embedded clause ellipted except for the clause-initial $w h$-phrase, which are contingent on the foregoing discourse ((25)); (iii) (almost) formulaic you-know-what-questions, which essentially serve to attract the interlocutor(s)' attention to what the questioner herself will instantly say ((26)); and (iv) declaratives followed by a comma, which precedes a wh-phrase forming part of a root information-requesting question that is otherwise ellipted ((27)).

$\begin{array}{lllll}\text { La maîtresse elle est } & \text { sympa. } & - & \text { Elle est } & \text { quoi? } \\ \text { the teacher she be-PRS-3sG } & \text { nice } & \text { she be-PRs-3sG } & \text { what } \\ \text { - Ben, sympa, gentille. } & & & & \\ \text { er nice, kind } & & & \end{array}$
(Fontcouverte, p. 89)

"The teacher is nice.' 'She is what?' 'Er, nice, kind.”

(25) Elle est $\quad$ morte
she be-PRs-3sg die-PST-PTCP she also the year last
Juste après mon père.
just after my father

7 This procedure thus likewise categorically excluded the consideration of any instances of interrogative constructions with more than one wh-phrase. 


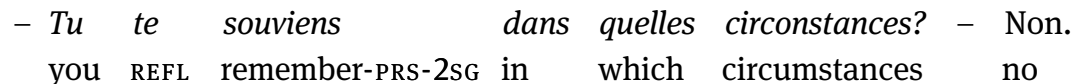
(Le Passager, p. 77)

"She also died last year. Just after my father.' 'Do you remember under what circumstances?' 'No.”

(26) - Tu sais quoi? Depuis ce midi, je pense you know-PRs-2sG what since this lunchtime I think-PRs-1sg

à Cendrillon à cause d' une connerie de publicité at Cinderella to cause of a stupidity of advertisement pour un Walt Disney [...]. for a Walt Disney

(Rêver, p. 252)

"You know what? Since lunchtime, I have been thinking of Cinderella for reasons of a stupid advertisement for a Walt Disney movie."

(27) - Les victimes ont le crâne rasé, pourquoi? the victims have-PRS-3PL the head shaved why (Lontano, p. 494)

"The victims have a shaved head. Why?"

While the latter construction was straightforwardly identified for reasons of the use of a specific punctuation mark, the other three constructions were unequivocally determined on the basis of the ready accessibility in the writings of the respective context of question constructions with a postverbal wh-phrase.

Table (1) lists the compiled writings along with pertinent details.

Table (1): Particulars on the writings underlying Zimmermann's (2018a) A Corpus of WH-in-Situ Interrogatives from Contemporary Hexagonal French Literary Prose Writing

\begin{tabular}{llcrr}
\hline title & name of author & year of 1st publication & pages & \# wh-in-situ \\
\hline Après la guerre & Le Corre, Hervé & 2014 & 568 & 38 \\
\hline Au revoir là-haut & Lemaitre, Pierre & 2013 & 604 & 38 \\
\hline Aveu de faiblesses & Viguier, Frédéric & 2017 & 183 & 56 \\
\hline La Ballade de l'enfant gris & Beaulieu, Baptiste & 2016 & 367 & 42 \\
\hline Brutale & $\begin{array}{l}\text { Bosco, Jacques- } \\
\text { Olivier }\end{array}$ & 2017 & 412 & 51 \\
\hline Chourmo & Izzo, Jean-Claude & 1996 & 246 & 53 \\
\hline Code 93 & Norek, Olivier & 2013 & 349 & 42 \\
\hline
\end{tabular}


Table (1): (continued)

\begin{tabular}{|c|c|c|c|c|}
\hline title & name of author & year of 1st publication & pages & \# wh-in-situ \\
\hline Condor & Férey, Caryl & 2016 & 487 & 117 \\
\hline Congo requiem & $\begin{array}{l}\text { Grangé, Jean- } \\
\text { Christophe }\end{array}$ & 2016 & 852 & 48 \\
\hline Du bruit sous le silence & Dessaint, Pascal & 1999 & 371 & 19 \\
\hline L'Échappée belle & Gavalda, Anna & 2009 & 122 & 16 \\
\hline L'Empire des loups & $\begin{array}{l}\text { Grangé, Jean- } \\
\text { Christophe }\end{array}$ & 2003 & 562 & 11 \\
\hline Les Enfants du néant & Descosse, Olivier & 2009 & 466 & 89 \\
\hline Fontcouverte & Dupuy, Daniel & 2007 & 439 & 27 \\
\hline Grossir le ciel & Bouysse, Franck & 2015 & 228 & 9 \\
\hline Hier encore, c'était l'été & Lestrange, Julie de & 2016 & 371 & 43 \\
\hline L'Immortel & $\begin{array}{l}\text { Giesbert, Franz- } \\
\text { Olivier }\end{array}$ & 2007 & 304 & 8 \\
\hline Kiffe kiffe demain & Guène, Faïza & 2004 & 180 & 5 \\
\hline $\begin{array}{l}\text { Les Larmes noires sur la } \\
\text { terre }\end{array}$ & Collette, Sandrine & 2017 & 370 & 67 \\
\hline Le Lessiveur & $\begin{array}{l}\text { Giesbert, Franz- } \\
\text { Olivier }\end{array}$ & 2009 & 279 & 9 \\
\hline Lontano & $\begin{array}{l}\text { Grangé, Jean- } \\
\text { Christophe }\end{array}$ & 2015 & 944 & 59 \\
\hline Maman a tort & Bussi, Michel & 2015 & 534 & 52 \\
\hline Les Marins perdus & Izzo, Jean-Claude & 1997 & 307 & 59 \\
\hline Miserere & $\begin{array}{l}\text { Grangé, Jean- } \\
\text { Christophe }\end{array}$ & 2008 & 626 & 30 \\
\hline N'oublier jamais & Bussi, Michel & 2014 & 534 & 33 \\
\hline Nuit & Minier, Bernard & 2017 & 587 & 75 \\
\hline Paris la nuit & Guez, Jérémie & 2011 & 119 & 10 \\
\hline Le Passager & $\begin{array}{l}\text { Grangé, Jean- } \\
\text { Christophe }\end{array}$ & 2011 & 966 & 64 \\
\hline Plateau & Bouysse, Franck & 2016 & 370 & 37 \\
\hline Plutôt crever & Férey, Caryl & 2002 & 240 & 41 \\
\hline $\begin{array}{l}\text { Prendre les loups pour des } \\
\text { chiens }\end{array}$ & Le Corre, Hervé & 2017 & 343 & 47 \\
\hline La Prophétie de Langley & Pouchairet, Pierre & 2017 & 272 & 64 \\
\hline
\end{tabular}


Table (1): (continued)

\begin{tabular}{llcrr}
\hline title & name of author & year of 1st publication & pages & \# wh-in-situ \\
\hline Les Rapaces & Brun, Thierry & 2016 & 304 & 56 \\
\hline Rêver & Thilliez, Franck & 2016 & 646 & 11 \\
\hline Les Rivières pourpres & $\begin{array}{l}\text { Grangé, Jean- } \\
\text { Christophe }\end{array}$ & 1998 & 433 & 5 \\
\hline Solea & Izzo, Jean-Claude & 1998 & 205 & 38 \\
\hline Le Soleil des mourants & Izzo, Jean-Claude & 1999 & 246 & 43 \\
\hline Surtensions & Norek, Olivier & 2016 & 464 & 88 \\
\hline Le Temps est assassin & Bussi, Michel & 2016 & 608 & 37 \\
\hline T'en souviens-tu, mon & Bussi, Michel & 2018 & 286 & 17 \\
Anaïs ? et autres nouvelles & & & & 23 \\
\hline Tension extrême & Forge, Sylvain & 2017 & 383 & 68 \\
\hline Territoires & Norek, Olivier & 2014 & 365 & 53 \\
\hline Total Khéops & Izzo, Jean-Claude & 1995 & 233 & 8 \\
\hline Trois jours et une vie & Lemaitre, Pierre & 2016 & 300 & 29 \\
\hline Un appartement à Paris & Musso, Guillaume & 2017 & 523 & 51 \\
\hline Les Violents de l'automne & Georget, Philippe & 2012 & 500 &
\end{tabular}

Intriguingly, in all of the writings on which the chosen corpus is based, the $w h$-insitu interrogative construction is exclusively confined to colloquially spontaneously conceived character speech, either directly assigned to the characters, as in (28), or indirectly, i.e. in the form of so-called discours indirect libre, as in (29).

(28) - Z' êtes qui p’tain? (Tension extrême, p. 68)

you be-PRS-2PL who fuck "Who the fuck are you?"

(29) [...] Cristián se demandait seulement si ça valait Cristián himself ask-IPFV-3sg only if this be.worth-IPFv-3sg le coup de continuer à vivre: il the blow of continue-InF to live-InF he était déjà veuf, il lui restait quoi? be-IPFV-3sg already widower it him remain-IPFV-3sg what (Condor, p. 98)

'Cristián just wondered whether it was worth continuing to live. He was already a widower. What remained for him to do?’ 
This state of affairs, along with the insight that the construction at issue is found with a wide range of characters from all socio-economic strata from all over France, is consonant with previous claims that the wh-in-situ interrogative construction is a trait of the colloquial spontaneous language spoken in Metropolitan France.

Having presented the particulars on the selection of an appropriate data basis, we will proceed with the investigation of the applicability of mainly syntactic restrictions on the wh-in-situ interrogative construction in Contemporary Hexagonal French.

\section{Investigating putative restrictions on the wh-in-situ interrogative construction in Contemporary Hexagonal French}

On the basis of the selected large-scale corpus, we now put to test each of the claims gathered in Section 2 and hereby explore the extent to which the wh-in-situ interrogative construction is constrained in the relevant respects in Contemporary Hexagonal French.

\subsection{Modals}

The corpus data show that the wh-in-situ interrogative construction is possible with modals in Contemporary Hexagonal French ((30)). In effect, 52 instances of either devoir 'to have to', pouvoir 'to be able to' or vouloir 'to want to' are encountered in 25 pieces of writings from altogether 17 authors.

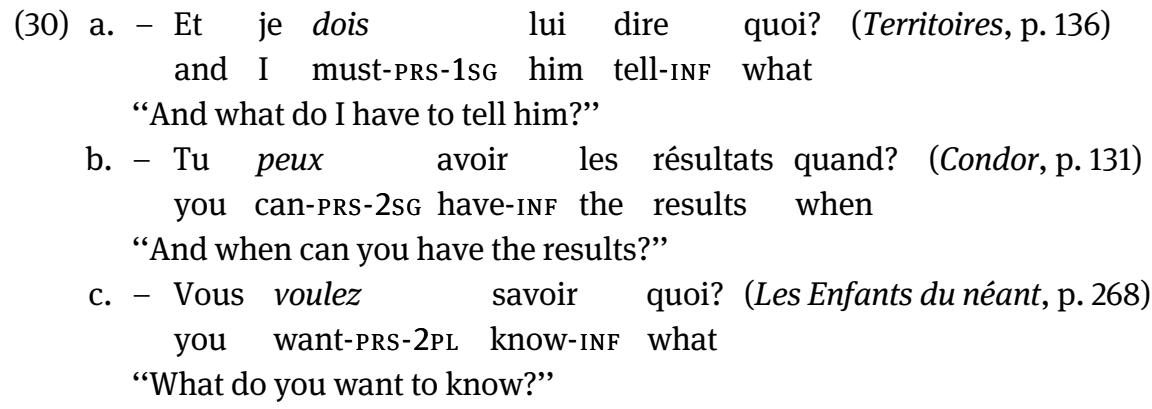




\subsection{Negative elements}

As to the occurrence of negative elements in the wh-in-situ interrogative construction, the corpus data are suggestive of the felicity of the occurrence of negative adverbs in this construction in Contemporary Hexagonal French, at least with an argumental $w h$-phrase, of which one instance was found ((31)).

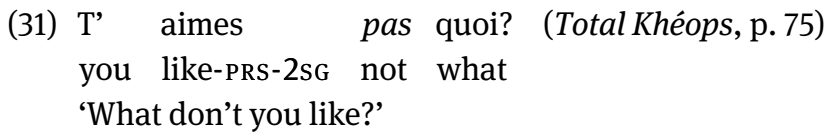

No relevant instances with an adjunct wh-phrase were, however, detected. Taking here as well as elsewhere in the paper a conservative stand, we shall refrain from inferring from this absence the ungrammaticality of the structure at issue in Contemporary Hexagonal French, since, as pointed out in Section 3, such absence may just as well be due to pure chance, in that the structure under discussion might accidentally not form part of the corpus chosen. As it stands, then, the possibility of the occurrence of negative adverbs with an adjunct wh-phrase in Contemporary Hexagonal French awaits further investigation.

Also, no instances of the wh-in-situ interrogative construction with either a negative argument or a negative adjective were encountered in the corpus, so that the issue of their felicity in Contemporary Hexagonal French is likewise still open.

\subsection{Non-presupposed situations}

The corpus data moreover expose that answers including rien 'nothing' and personne 'nobody' are possible and, thus, that the wh-in-situ interrogative construction in Contemporary Hexagonal French can appear in a non-presupposed situation ((32)). In particular, 16 pertinent instances were detected in eight writings stemming from eight authors.

(32) a. Mais aujourd'hui il $\mathrm{y}$ a
but today
- Rien, rien there have-PRs-3sG what mister Muñez
nothing nothing of.the all nothing of.the all because
qu' il n' $\mathrm{d}$ a
that it not there have-PRs-3sG never nothing have-PST-PTCP
(Condor, p. 450)


'But, today, what is there, Mister Muñez?' 'Nothing, nothing at all! Nothing at all, since there has never been anything!"

b. À part Roz-Tagle, tu as prévenu qui d' autre? to part Roz-Tagle you have-PRS-2sG tell-PST-PTCP who of else

- Personne. (Condor, p. 271) nobody

“Apart from Roz-Tagle, who else have you told?' 'Nobody."

More generally, the corpus data exhibit that the $w h$-in-situ interrogative construction in Contemporary Hexagonal French is appropriate as a discourse opener, a case in point being inquiries about the time of day such as Il est quelle heure? 'What's the time?' ((33)) (cf. also Adli 2006; Kaiser/Quaglia 2015).

(33) J' étais dans le cirage. Noir. [...] J' ouvris

I be-IPFv-1sg in the shoe.cream black I open-PST-1sG les yeux. Marie-Lou me sourit. [...] - Ça va? the eyes Marie-Lou me smile-PST-3sg this go-Prs-3sg Je fis oui de la tête, fermai les yeux. [...]

I make-PST-1sg yes of the head close-PST-1sg the eyes

- Il est quelle heure? je dis. (Total Khéops, p.125f.) it be-PRS-3sg which hour I say-PST-1sG

'I was half-conscious. Blackout. I opened my eyes. Marie-Lou smiled at me. 'How are you?' I nodded, closed my eyes. 'What's the time?', I said.'

\subsection{Universally quantified elements preceding the wh-phrase}

As far as the occurrence in the wh-in-situ interrogative construction of universally quantified elements to the left of the wh-phrase is concerned, the corpus data provide no single such instance, leaving the issue of their felicity in Contemporary Hexagonal French as yet unsolved.

\subsection{Quantifiers quantifying at a distance}

Regarding the occurrence of the $w h$-in-situ interrogative construction with quantifiers that quantify at a distance, no pertinent instances were detected in the corpus. The issue of their appropriateness in Contemporary Hexagonal French thus awaits further investigation. 


\subsection{Focus markers}

The corpus data likewise do not provide any instances of the wh-in-situ interrogative construction with focus markers, a state of affairs that leaves the issue of their possibility in Contemporary Hexagonal French open.

\subsection{Non-exhaustivity}

In addition, no instances of the wh-in-situ interrogative construction with par exemple 'for example' form part of the corpus. The issue of their availability and, hence, that of non-exhaustivity in Contemporary Hexagonal French thus remains unsolved.

\subsection{Wh-phrases being the complement of specific DPs}

As far as the occurrence of a wh-phrase that is the complement of a specific DP in the wh-in-situ interrogative construction is concerned, the corpus data suggest that it is licit in Contemporary Hexagonal French, as reflected by the existence of one pertinent instance ((34)).

(34) - C' était le fils de qui? (Congo requiem, p. 463)
this be-IPFV-3sG the son of who
'Whose son is this?'

\subsection{Set expressions}

Concerning the occurrence of the wh-in-situ interrogative construction as set expressions such as How is ... ? and What's the matter?, the corpus data indicate that, at least with the former expression, this is possible in Contemporary Hexagonal French. In total, one instance of the expression How is ... ? was found ((35)).

(35) Il va comment? - Mal... (Maman a tort, p. 492) he go-PRs-3sg how bad "How is he?' 'Bad ..." 


\subsection{Adjunct wh-phrases}

Regarding the occurrence of the $w h$-in-situ interrogative construction with an adjunct $w h$-phrase, the corpus data show that it is in principle licit in Contemporary Hexagonal French ((36); cf. also (30b) above). Specifically, almost all (a total of 44 out of 46) writings feature such instances, amounting to a total of 216 instances.

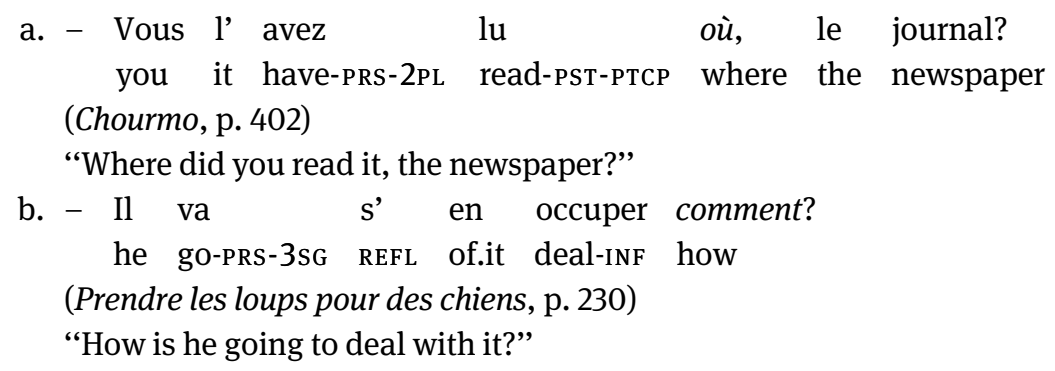

What is more, the wh-in-situ interrogative construction is also felicitous with an adjunct wh-phrase that occurs clause-finally, following an object ((37); cf. also (30b) above). In total, the corpus data display 28 pertinent instances in 20 writings from 16 authors.

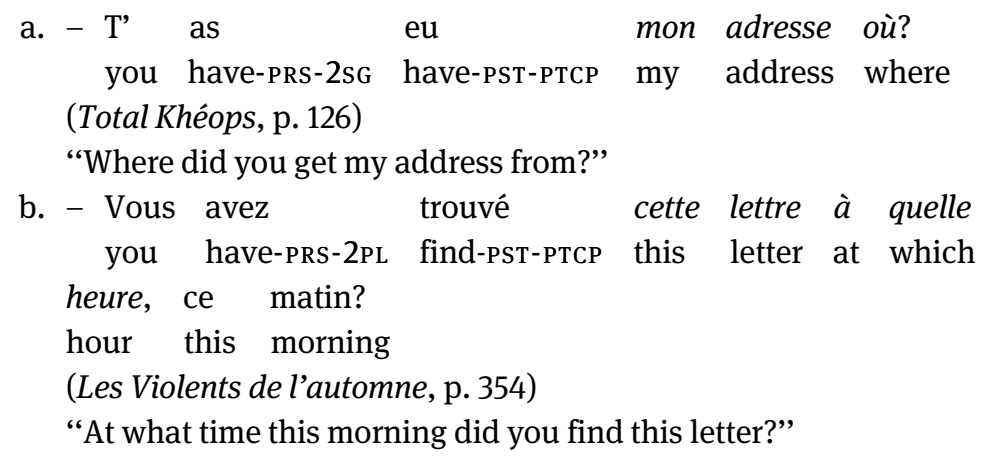

As for the issue of the occurrence of pourquoi 'why' in the wh-in-situ interrogative construction, there are four relevant instances in the corpus ((38)), encountered in two writings from two authors. 
pourquoi, répéta-t elle [...] (Chourmo, p. 304)

POURQUOI repeat-PST-3SG she

"What is it, Mourad?' 'What is it?', she asked.'

b. - C' est pourquoi? (Chourmo, p. 386)

this be-PRS-3SG POURQUOI

"What is it?"

c. - $\mathrm{Tu}$ es là pourquoi, alors? (Brutale, p. 284)

you be-PRS-2sG there POURQUOI then

"What are you here for, then?"

Still, these instances had probably better be taken with a grain of salt, as various otherwise identical or highly similar instances in comparable contexts are found in the corpus that have pour quoi 'what for', rather than pourquoi ((39)).

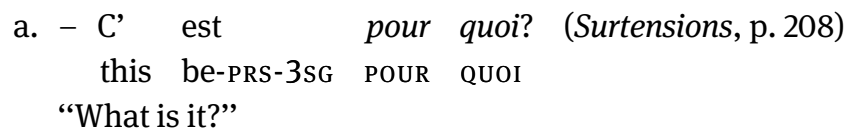

b. [...], t' es là pour quoi? (Aveu defaiblesses, p. 72) you be-PRs-2sG there POUR QUOI 'What are you here for?'

Given this conflicting state of affairs, we refrain from adopting a clear stance on the possibility of the occurrence of pourquoi 'why' in the wh-in-situ interrogative construction in Contemporary Hexagonal French, which thus awaits further investigation.

\subsection{QUEL in predicative contexts}

As to the availability of the $w h$-in-situ interrogative construction in predicative contexts with the wh-pronominal QUEL 'which one', the corpus data provide no such instances, a state of affairs that leaves open the issue of their possibility in Contemporary Hexagonal French.

\subsection{Wh-the hell-phrases}

Likewise, no instances of the wh-in-situ interrogative construction with a wh-the hell-phrase were encountered in the corpus. The issue of their possibility in Contemporary Hexagonal French thus remains unresolved. 


\subsection{Single full DP subject}

Concerning the issue of whether the wh-in-situ interrogative construction is appropriate with a full DP subject that is not doubled by a co-referential clitic subject pronoun, the corpus data reveal that this is indeed the case in Contemporary Hexagonal French ((40)). In particular, 18 instances were found in 11 writings stemming from 10 writers.

(40)
a. - Tu m' as
dit
que Serge Spy était you me have-PRs-2sg say-PST-PTcP that Serge Spy be-IPFv-3sg quoi déjà? (Du bruit sous le silence, p. 99)
what again

"What did you say that Serge Spy was again?"
b. Sam, le dernier appel remonte à quelle heure?
Sam the last call date.back-PRs-3sg to which hour (Code 93, p. 83)

'Sam, to what time does the last call date back?'

\subsection{Long extraction contexts}

Regarding the occurrence of the wh-in-situ interrogative construction in embedded clauses in the context of long extraction, the corpus data show that this is licit in Contemporary Hexagonal French, irrespective of the kind of pertinent root lexical verb ((41); cf. also (40a)). There are actually 22 relevant instances, detected in 14 writings from 11 authors.
(41) a. - $\mathrm{Tu}$ voulais que je fasse quoi? you want-IPFV-2sG that I make-SBJv-1sG what (Nuit, p. 467)
"What did you want me to do?"

b. Et vous pensez qu' il risque quoi? and you think-PRS-2PL that he risk-PRS-3SG what (Territoires, p. 352)

'And what do you think that he risks?' 


\subsection{Non-finite embedded clauses with a complementizer}

Turning next to the occurrence of the $w h$-in-situ interrogative construction in a non-finite embedded clause with a complementizer, the corpus data provide four such instances in three writings from three authors ((42)), a finding that attests to their availability in Contemporary Hexagonal French.

a. [...] je veux bien discuter nature avec toi, mais
I want-PRs-1sG well discuss-InF nature with you but
t' essaies de me dire quoi?
you try-PRs-2sG of me say-INF what

(Surtensions, p. 326)

'I would really like to discuss nature with you, but what are you trying to tell me?'

b. - T' attends de voir quoi?

you wait-PRS-2SG of see-INF what

(Hier encore, c'était l'été, p. 304)

"What are you waiting to see?"

\subsection{Finite embedded clauses depending on a root interrogative verb}

As for, finally, the availability of the wh-in-situ interrogative construction in a finite embedded clause depending on a root interrogative verb, no such instances have been encountered in the corpus. The issue of their felicity in Contemporary Hexagonal French thus awaits further investigation.

\subsection{Summary}

From the preceding investigation it follows that, at least as far as the present-day French of Metropolitan France is concerned, the $w h$-in-situ interrogative construction is not subject to a fair number of the putative restrictions argued to hold regarding, in particular, the level of syntax. Specifically, contrary to what has been claimed - and, at times, in line with opposing views - the results presently arrived at clearly show that the wh-in-situ interrogative construction in Contemporary Hexagonal French is not subject to any restrictions whatsoever relating to the occurrence of modals, negative adverbs with an argumental wh-phrase, adjunct wh-phrases or single full DP subjects, nor to the occurrence of this 
construction in non-presupposed situations, in long extraction contexts, in nonfinite embedded clauses with a complementizer, with wh-phrases being the complement of specific DPs, or as set expressions.

Whether any of the other putative restrictions on the wh-in-situ interrogative construction hold in Contemporary Hexagonal French remains yet to be determined, given, as expounded on earlier, the conservative stand taken here when particular structures are absent in the underlying corpus. Further investigation is therefore needed regarding the possibility of the occurrence in the construction under discussion in the present-day French of Metropolitan France of negative adverbs with an adjunct wh-phrase, negative arguments, negative adjectives, universal quantifiers as well as universal quantificational adverbs to the left of the wh-phrase, quantifiers quantifying at a distance, focus markers, non-exhaustivity, pronominal QUEL 'which one' in predicative contexts, and wh-the hellphrases as well as the felicity in finite embedded clauses depending on a root interrogative verb, along with the availability of pourquoi 'why'.

To allow for a straightforward overview of the insights presently gained, Table (2) succinctly summarizes the findings of this section. As this summary shows, (at least) 10 of the relevant set of putative restrictions evidently do not hold in the wh-in-situ interrogative construction in Contemporary Hexagonal French.

Table (2): Putative restrictions, respectively, not holding (' $x$ ') and awaiting further investigation ('?') in the wh-in-situ interrogative construction in Contemporary Hexagonal French

\begin{tabular}{|c|c|}
\hline $\begin{array}{l}\text { issue: } \\
\text { restriction regarding the occurrence ... }\end{array}$ & $\begin{array}{l}\text { interrogative wh-in-situ } \\
\text { in Contemporary Hexagonal French }\end{array}$ \\
\hline ... of modals & $x$ \\
\hline ... of negative adverbs with an argumental wh-phrase & $x$ \\
\hline$\ldots$ of negative adverbs with an adjunct $w h$-phrase & $?$ \\
\hline ... of negative arguments & ? \\
\hline ... of negative adjectives & $?$ \\
\hline ... in non-presupposed situations & $x$ \\
\hline$\ldots$ of universal quantifiers preceding the $w h$-phrase & $?$ \\
\hline $\begin{array}{l}\ldots \text { of universal quantificational adverbs preceding } \\
\text { the } w h \text {-phrase }\end{array}$ & $?$ \\
\hline ... of quantifiers quantifying at a distance & ? \\
\hline ... of focus markers & $?$ \\
\hline ... with non-exhaustivity & ? \\
\hline
\end{tabular}


Table (2): (continued)

\begin{tabular}{ll}
\hline $\begin{array}{l}\text { issue: } \\
\text { restriction regarding the occurrence ... }\end{array}$ & $\begin{array}{l}\text { interrogative } \text { wh-in-situ } \\
\text { in Contemporary Hexagonal French }\end{array}$ \\
\hline$\ldots$ of wh-phrases being the complement of specific DPs & $x$ \\
\hline$\ldots$ as set expressions & $x$ \\
\hline$\ldots$ of adjunct wh-phrases & $x$ \\
\hline$\ldots$ of adjunct wh-phrases following an object & $\chi$ \\
\hline$\ldots$ of pourquoi 'why' & $?$ \\
\hline$\ldots$ of $Q U E L$ in predicative contexts & $?$ \\
\hline$\ldots$ of wh-the hell-phrases & $?$ \\
\hline$\ldots$ of single full DP subjects & $\chi$ \\
\hline$\ldots$ in long extraction contexts & $x$ \\
\hline$\ldots$ in non-finite embedded clauses with a complementizer & $\chi$ \\
\hline$\ldots$ in finite embedded clauses depending on a root & $?$ \\
\hline interrogative verb &
\end{tabular}

In the following section, we will look into the possible relevance of further factors which have not been thoroughly explored in the literature, yet might conceivably bear on the availability of the $w h$-in-situ interrogative construction in Contemporary Hexagonal French.

\section{Exploring further traits of the wh-in-situ interrogative construction in Contemporary Hexagonal French}

We presently turn to an investigation of a number of morphological and syntactic issues that have not been systematically tackled so far to establish whether one or several of these have an impact on the felicity of the wh-in-situ interrogative construction in Contemporary Hexagonal French. By doing so, we aim to deepen the current knowledge of the particulars of this construction in the latter variety, while, at the same time, drawing attention to the possible existence of further restrictions in other diatopic varieties of Modern French. As to morphology, we explore the extent to which the wh-in-situ interrogative construction is available in Contemporary Hexagonal French with respect to the various tenses and moods known to typically exist in the colloquial spontaneous speech of this variety as 
well as to passive voice. For it has been suggested that the length of the verbal complex, which in fact strongly correlates with tense, mood, and voice, may have an impact (cf. Coveney 1995). Regarding syntax, we look into non-finite embedded clauses with no infinitival complementizer in view of the focus in the literature on such clauses with an infinitival complementizer as well as into verb class and subject type, which have been argued to be relevant regarding the whex-situ interrogative construction in (1a') (cf. Kayne/Pollock 2001). As before, the investigation is based on the selected large-scale corpus expounded on in Section 3.

\subsection{Tense and mood}

Beginning with the exploration of morphological issues, the corpus data show that the wh-in-situ interrogative construction in Contemporary Hexagonal French is not subject to any restrictions relating to tense or mood (with the exception of the imperative, with which interrogatives quite generally are incompatible), as it is encountered with all tenses and moods typically found in colloquial spontaneous speech of the variety at hand, viz., present indicative ((43a); cf. also (30ac), (31), (32a), (33), (35), (38), (39), (40b), (41b)), imperfect indicative ((43b); cf. also (40a)), simple past indicative ((43c); cf. also (32b), (34), (36a), (37a-b)), pluperfect indicative $((43 \mathrm{~d}))$, simple future indicative $((43 \mathrm{e}))$, compound future indicative ((43f); cf. also (36b)), present subjunctive ((43g); cf. also (41a)), present conditional ((43h)), past conditional ((43i)).

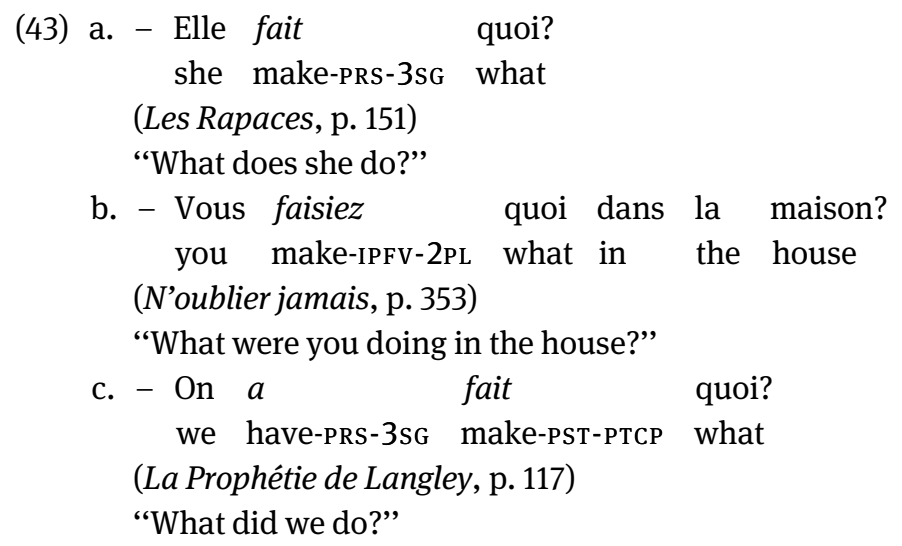


d. - Vous aviez prévu quoi, pour calmer le jeu? you have-IPFV-2PL plan-PST-PTCP what for calm-INF the game (Territoires, p. 366)

"What had you planned to calm things down?"

e. - Et toi, tu feras quoi quand tu verras

and you you make-Fut-2sg what when you see-FUt-2sG

quelqu'un en gros plan dans ta lunette?

someone in big shot in your telescope

(Après la guerre, p. 248)

"And you? What will you do when you see someone close up through your telescope?”

f. - Ils vont faire quoi là-bas?

they go-PRs-3PL make-INF what there

(Condor, p. 410)

"What will they do there?"

g. - Tu veux que je fasse quoi? you want-PRs-2sG that I make-sBJv-1sG what

(Maman a tort, p. 212)

"What do you want me to do?"

h. $\mathrm{Tu}$ ferais quoi?

you make-cond-2sg what

(Du bruit sous le silence, $\mathrm{p} .75$ )

'What would you do?'

i. Vous auriez fait quoi à ma place?

you have-COND-2PL make-PST-PTCP what in my place

(Le Temps est assassin, p. 197)

'What would you have done in my place?'

\subsection{Passive voice}

As for passive voice, the corpus data expose that it is compatible with the $w h$-insitu interrogative construction in Contemporary Hexagonal French ((44)).

(44) a. - Et toi, t' es saisi par qui? and you you be-PRs-2sG call.on-PST-PTCP by who (Miserere, p. 77)

"And you? By whom were you called?"

b. Et toi, pour que tu viennes te balancer

and you for that you come-sBjv-2sG you sack-INF 
tout seul tu as été payé combien? all alone you have-PRS-2sG be-PST-PTCP pay-PST-PTCP how.much (Territoires, p. 293)

'And you? For you to come and sack yourself on your own, how much were you paid?'

\subsection{Non-finite embedded clauses without a complementizer}

Proceeding with syntactic issues, we first tackle non-finite embedded clauses with no infinitival complementizer. The corpus data show that, with these, the wh-insitu interrogative construction is possible in Contemporary Hexagonal French when the root clause has a causative verb ((45a)), a control verb ((45b)) or an E(xceptional)C(ase)M(arking) verb ((45c)).

(45) a. Et ils font passer ça comment? (Territoires, p. 309)

and they make-PRS-3PL pass-INF this how

'And how do they get it through?'

b. - $\mathrm{Tu}$ comptais faire quoi?

you plan-IPFv-2sg make-INF what

(Prendre les loups pour des chiens, p. 333)

"What did you plan to do?"

c. T' as vu jouer ça où?

you have-PRS-2sg see-PST-PTCP play-INF this where

(Les Violents de l'automne, p. 106)

'Where did you see that being played?'

\subsection{Verb class}

Turning to verb class, the pertinent analysis of the corpus data reveals that the wh-in-situ interrogative construction is available in Contemporary Hexagonal French with all verb classes, viz., ditransitives ((46a)), direct transitives ((46b); cf. also (31), (32), (36a), (37a-b), (41)), indirect transitives ((46c); cf. also (40c)), unergatives ((46d)), unaccusatives ((46e); cf. also (40b)), and reflexives ((46f); cf. also (36b)).

(46) a. Et puis il dirait quoi à Vera? (Condor, p. 64) and then he tell-cond-3sg what to Vera 'And then, what would he tell Vera?' 


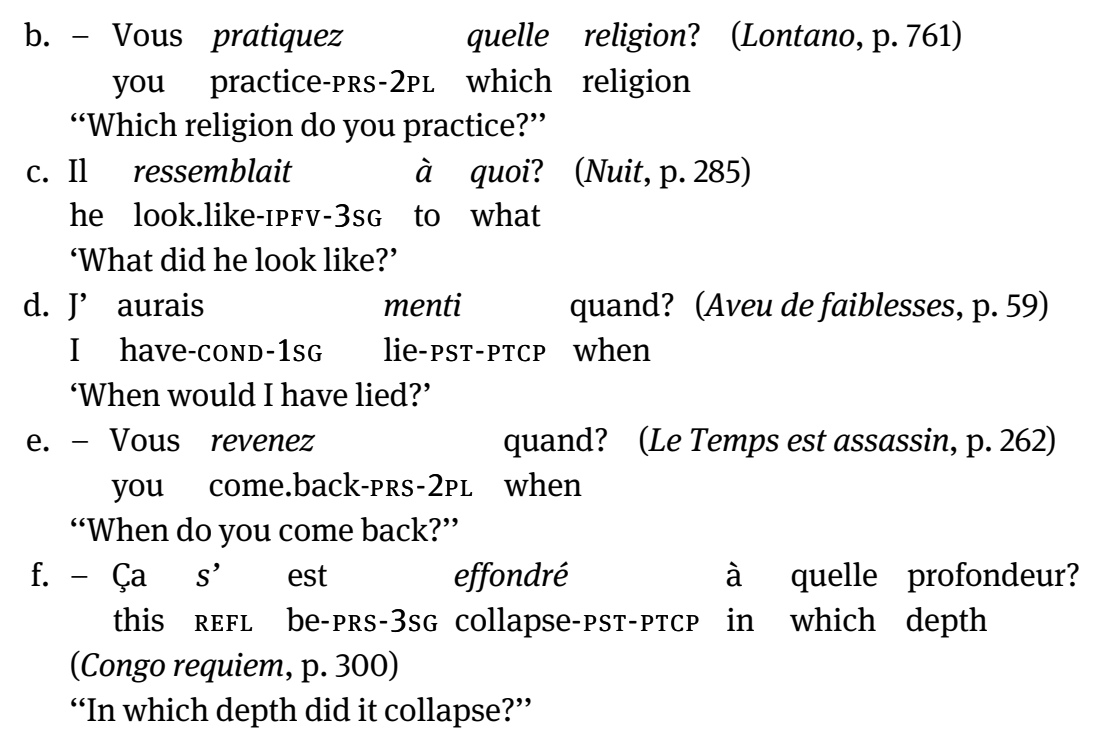

\subsection{Subject type}

The last issue to be addressed, that of subject type, has actually already been approached to some extent in Section 4, where we have established that, in the $w h$-in-situ interrogative construction in Contemporary Hexagonal French, the occurrence of (definite) full DP subjects is licit (cf. (40)), while that of universally quantified subjects is as yet unclear, given the radical absence of pertinent instances. The corpus data furthermore show that the occurrence of clitic subject pronouns (cf. this section as well as Section 4 for a myriad of examples), of both clitic and strong demonstrative pronouns ((47); cf. also (34), (38a), (45f)) as well as of null, i.e. phonologically non-overt, subjects ((48)) is felicitous ${ }^{8}$.

(47) a. - C’ est quoi exactement? (Un appartement à Paris, p. 202) this be-PRs-3sg what exactly

"What exactly is this?"

8 Cf. Zimmermann (2014, 2018b) and Zimmermann/Kaiser (2014) for extensive discussion on the availability of null subjects in, respectively, the formal and the colloquial register of Hexagonal French. 
b. - Cela pourrait prendre combien de temps? (Brutale, p. 336) this can-Cond-3sg take-inF how.much of time

"How much time could this take?"

(48) a. - Faites quoi, là? (La Prophétie de Langley, p. 141) make-PRS-2PL what there

"What are you doing there?"

b. - Y en a combien? (L'Échappée belle, p. 63)

there of.it have-PRs-3sg how.many

"How many are there?"

On the contrary, no relevant instances of the occurrence of indefinite full DP subjects and pronouns were found in the selected large-scale corpus, a situation which, as expounded previously, needs further investigation. Fundamentally, should this and other investigations indicate the infelicity of the occurrence of indefinite full DP subjects and pronouns, along with that of universally quantified subjects, then the $w h$-in-situ interrogative construction in Contemporary Hexagonal French would stand out due to a "counter-indefiniteness effect" (Kayne/ Pollock 2001, 118), in that the subject element would be required to be definite, at least etymologically, as is the case with the subject expletive. Kayne/Pollock originally conceptualized the notion of counter-indefiniteness effect with respect to the wh-ex-situ interrogative construction in (1a') above.

\subsection{Summary}

Summarizing the preceding investigation of further factors that might conceivably bear on the availability of the wh-in-situ interrogative construction in the present-day French of Metropolitan France, no restrictions whatsoever hold regarding tense, mood, passive voice, non-finite embedded clauses without a complementizer as well as verb class. Yet, as far as subject type is concerned, an additional restriction possibly exists in the form of a counter-indefiniteness effect.

\section{Conclusion}

Among the various structures of information-requesting wh-questions in Modern French, the one in which the wh-phrase occurs in post-verbal position has led to an increasingly fierce debate on its particulars. Essentially, many claims have been put forth that are strongly suggestive of the view that the wh-in-situ inter- 
rogative construction is governed by numerous restrictions pertaining primarily to the level of syntax. On the basis of a specially designed large-scale corpus instantiating the present-day French of Metropolitan France, a large set of putative restrictions was put to test. It was hereby uncovered that, in the diatopic modern variety at issue, a fair number of these do not hold. In addition, the existence of further restrictions was explored. It was hereby found that, whereas tense, mood, passive voice, verb class as well as non-finite embedded clauses with no infinitival complementizer do not bear on the availability of the wh-in-situ interrogative construction in the variety of French discussed, a restriction possibly holds that relates to the specificity of the subject. Future research will have to determine the existence of this restriction in Contemporary Hexagonal French, along with those putative restrictions for which no pertinent instances have been encountered in the corpus chosen. Future studies will also need to investigate possible underlying pragmatic conditions, to explore the extent to which the set of putative restrictions gathered in this paper hold in other diatopic varieties of Modern French, and - should one or several such restrictions exist - to provide a comprehensive formal approach.

\section{References}

Adli, Aria (2006): "French $w h$-in-situ questions and syntactic optionality: evidence from three data types", in: Zeitschrift für Sprachwissenschaft 25/2, 163-203.

Ambar, Manuela/Veloso, Rita (2001): "On the nature of wh-phrases - word order and wh-in-situ. Evidence from Portuguese, French, Hungarian and Tetum”, in: Yves D’Hulst/Johan Rooryck/ Jan Schroten (eds.), Romance Languages and Linguistic Theory 1999. Selected Papers from 'Going Romance' 1999, Leiden, 9-11 December, Amsterdam, Benjamins, 1-37.

Baunaz, Lena (2005): "The syntax and semantics of wh in-situ and existentials: the case of French", in: Leiden Working Papers in Linguistics 2/2, 1-27.

Baunaz, Lena (2011): The Grammar of French Quantification, Dordrecht, Springer.

Baunaz, Lena/Patin, Cédric (2011): "Prosody refers to semantic factors: evidence from French wh-words", in: Hi-Yon Yoo/Elisabeth Delais-Roussarie (eds.), Actes d'Interface Discours \& Prosodie, 93-107. http://makino.linguist.jussieu.fr/idp09/actes_en.html (6 August 2018).

Bayer, Josef (2006): “Wh-in-situ”, in: Martin Everaert/Henk van Riemsdijk (eds.), The Blackwell Companion to Syntax. Volume 5, Malden, Blackwell, 376-438.

Bayer, Josef/Cheng, Lisa Lai-Shen (2017): “WH-in-situ”, in: Martin Everaert/Henk van Riemsdijk (eds.), The Wiley Blackwell Companion to Syntax. Volume 8: U-Z, Hoboken, Wiley Blackwell, 4979-5022.

Behnstedt, Peter (1973): Viens-tu? Est-ce que tu viens? Tu viens? Formen und Strukturen des direkten Fragesatzes im Französischen, Tübingen, Narr.

Boeckx, Cédric (1999): “Decomposing French questions”, in: University of Pennsylvania Working Papers in Linguistics 6/1, 69-80. 
Boeckx, Cédric/Stateva, Penka/Stepanov, Arthur (2001): “Optionality, presupposition, and wh-in situ in French”, in: Joaquim Camps/Caroline R. Wiltshire (eds.), Romance Syntax, Semantics and L2 Acquisition. Selected Papers from the 30th Linguistic Symposium on Romance Languages. Gainesville, Florida, February 2000, Amsterdam, Benjamins, 57-71.

Bošković, Željko (1998): “LF movement and the Minimalist Program”, in: Pius N. Tamanji/Kiyomi Kusumoto (eds.), Proceedings of NELS 28, Amherst, MA, GLSA, 43-57.

Bošković, Željko (2000): “Sometimes in [Spec, CP], sometimes in situ”, in: Roger Martin/David Michaels/Juan Uriagereka (eds.), Step by Step. Essays on Minimalist Syntax in Honor of Howard Lasnik, Cambridge, MA, MIT Press, 53-88.

Chang, Lisa (1997): Wh-in-situ phenomena in French, MA thesis, University of British Columbia.

Cheng, Lisa Lai-Shen/Rooryck, Johan (2000): “Licensing wh-in-situ”, in: Syntax 3/1, 1-19.

Coveney, Aidan (1989): “Pragmatic constraints on interrogatives in spoken French”, in: York Papers in Linguistics 3, 89-99.

Coveney, Aidan (1995): “The use of the QU-final interrogative structure in spoken French”, in: French Language Studies 5, 143-171.

D’Introno, Francesco (2000): “Teoría generativa y estudios sintácticos sobre el español de Puerto Rico y el Caribe”, in: Revista de Estudios Hispánicos 27/1, 107-147.

Etxepare, Ricardo/Uribe-Etxebarria, Myriam (2005): “In-situ wh-phrases in Spanish: locality and quantification”, in: Recherches linguistiques de Vincennes 33, 9-34.

Hamlaoui, Fatima (2011): “On the role of phonology and discourse in Francilian French whquestions”, in: Journal of Linguistics 47, 129-162.

Kaiser, Georg/Quaglia, Stefano (2015): “In search of wh-in-situ in Romance: An investigation in detective stories”, in: Ellen Brandner/Anna Czypionka/Constantin Freitag/Andreas Trotzke (eds.), Charting the Landscape of Linguistics: On the Scope of Josef Bayer's Work. Webschrift for Josef Bayer, 92-103. http://ling.uni-konstanz.de/pages/WebschriftBayer/2015/ contents_files/KaiserQuaglia.pdf (6 August 2018).

Kayne, Richard S./Pollock, Jean-Yves (2001): “New thoughts on Stylistic Inversion”, in: Aafke Hulk/Jean-Yves Pollock (eds.), Subject Inversion in Romance and the Theory of Universal Grammar, Oxford, Oxford University Press, 107-161.

Koch, Peter/Oesterreicher, Wulf ( $\left.{ }^{2} 2011\right):$ Gesprochene Sprache in der Romania. Französisch, Italienisch, Spanisch, Berlin, De Gruyter, 2nd, updated, and extended edn.

Kremnitz, Georg (2015): Frankreichs Sprachen, Berlin, De Gruyter.

Lipski, John M. (1977): “Preposed subjects in questions: Some considerations”, in: Hispania 60/ 1, 61-67.

Mathieu, Eric (1999): “WH in situ and the intervention effect”, in: UCL Working Papers in Linguistics 11, 441-472.

Mathieu, Eric (2002): The syntax of non-canonical quantification: a comparative study, PhD thesis, University College London.

Mathieu, Eric (2004): “The mapping of form and interpretation: the case of optional WH-movement in French", in: Lingua 114, 1090-1132.

Mathieu, Eric (2009): “Les questions en français: micro- et macro-variation”, in: France Martineau/Raymond Mougeon/Terry Nadasdi/Mireille Tremblay (eds.), Le français d'ici: études linguistiques et sociolinguistiques sur la variation du français au Québec et en Ontario, Toronto, GREF, 37-66.

Mathieu, Eric (2016): “The wh parameter and radical externalization”, in: Luis Eguren/Olga Fernández-Soriano/Amaya Mendikoetxea (eds.), Rethinking Parameters, New York, Oxford University Press, 252-290. 
Martínez-Sanz, Cristina (2011): Null and overt subjects in a variable system: The case of Dominican Spanish, PhD thesis, University of Ottawa.

Munaro, Nicola/Poletto, Cecilia/Pollock, Jean-Yves (2001): “Eppur si muove! On comparing French and Bellunese wh-movement”, in: Pierre Pica (ed.), Linguistic Variation Yearbook1, Amsterdam, Benjamins, 147-180.

Obenauer, Hans-Georg (1994): Aspects de la syntaxe A-barre. Effets d'intervention et mouvements de quantifieurs, Thèse de Doctorat d’État, Université de Paris VIII.

Oiry, Magda (2011): "A case of true optionality: $w h$-in situ patterns like long movement in French", in: Linguistic Analysis 37/1-2, 1-28.

Peralta Céspedes, Manuel (2017): “El español dominicano en contacto con el español madrileño: El caso del sujeto en las interrogativas directas”, in: Christine Felbeck/Andre Klump (eds.), Dominicanidad / Dominicanity. Perspectivas de un concepto (trans-)nacional / Perspectives on a (trans-)national concept, Frankfurt a.M., Lang, 93-111.

Poletto, Cecilia/Pollock, Jean-Yves (2009): “Another look at wh-questions in Romance: the case of Mendrisiotto and its consequences for the analysis of French wh-in-situ and embedded interrogatives", in: Danièle Torck/W. Leo Wetzels (eds.), Romance Languages and Linguistic Theory 2006: Selected papers from 'Going Romance’, Amsterdam, 7-9 December 2006, Amsterdam, Benjamins, 199-258.

Pollock, Jean-Yves (1998): Langage et cognition. Introduction au programme minimaliste de la grammaire générative, Paris, Presses Universitaires de France.

Shlonsky, Ur (2012): “Notes on wh in situ in French”, in: Laura Brugé/Anna Cardinaletti/Giuliana Giusti/Nicola Munaro/Cecilia Poletto (eds.), Functional Heads. The Cartography of Syntactic Structures. Volume 7, Oxford, Oxford University Press, 242-252.

Söll, Ludwig (1985): Gesprochenes und geschriebenes Französisch, Berlin, Schmidt.

Starke, Michal (2001): Move dissolves into merge: a theory of locality, PhD thesis, University of Geneva.

Uribe-Etxebarria, Myriam (2002): “In-situ questions and masked movement”, in: Pierre Pica (ed.), Linguistic Variation Yearbook 2, Amsterdam, Benjamins, 217-257.

Valdman, Albert (1968): “Normes pédagogiques: Les structures interrogatives du français”, in: International Review of Applied Linguistics in Language Teaching 5, 3-10.

Zimmermann, Michael (2014): Expletive and Referential Subject Pronouns in Medieval French, Berlin, De Gruyter.

Zimmermann, Michael (2018a): A Corpus of WH-in-Situ Interrogatives from Contemporary Hexagonal French Literary Prose Writing, Konstanz, Fachbereich Linguistik der Universität Konstanz. [Upon approval by the publishing houses, the corpus will be accessible at www.ortolang.fr.]

Zimmermann, Michael (2018b): "Null subjects, expletives, and the status of Medieval French", in: Federica Cognola/Jan Casalicchio (eds.), Null Subjects in Generative Grammar. A Synchronic and Diachronic Perspective, Oxford, Oxford University Press, 70-93.

Zimmermann, Michael/Kaiser, Georg A. (2014): “On expletive subject pronoun drop in Colloquial French”, in: Journal of French Language Studies 24, 107-126.

Zubizarreta, María Luisa (2003): "Intervention effects in the French wh-in-situ construction. Syntax or interpretation?”, in: Rafael Núñez-Cedeño/Luis López/Richard Cameron (eds.), A Romance Perspective on Language Knowledge and Use. Selected Papers from the 31th Linguistic Symposium on Romance Languages (LSRL), Chicago, 19-22 April 2001, Amsterdam, Benjamins, 359-379. 
Zuckerman, Shalom/Hulk, Aafke (2001): “Acquiring optionality in French wh-questions: an experimental study”, in: Revue québécoise de linguistique 30/2, 71-97.

\section{Literary sources underlying Zimmermann (2018a)}

Hervé le Corre. Après la guerre. Paris, Payot \& Rivages. 2016 [2014].

Pierre Lemaitre. Au revoir là-haut. Paris, Librairie Générale Française. 2015 [2013].

Frédéric Viguier. Aveu de faiblesses. Paris, Librairie Générale Française. 2018 [2017].

Baptiste Beaulieu. La Ballade de l'enfant gris. Paris, Librairie Générale Française. 2018 [2016]. Jacques-Olivier Bosco. Brutale. Paris, Pocket. 2018 [2017].

Olivier Norek. Code 93. Paris, Pocket. 2017 [2013].

Caryl Férey. Condor. Paris, Gallimard. 2018 [2016].

Jean-Christophe Grangé. Congo requiem. Paris, Librairie Générale Française. 2017 [2016].

Pascal Dessaint. Du bruit sous le silence. Paris, Payot \& Rivages. 2017 [1999].

Anna Gavalda. L'Échappée belle. Paris, J'ai lu. 2018 [2009].

Jean-Christophe Grangé. L'Empire des loups. Paris, Librairie Générale Française. 2016 [2003].

Olivier Descosse. Les Enfants du néant. Paris, J'ai lu. 2010 [2009].

Jean-Claude Izzo. Fabio Montale. Total Khéops. Chourmo. Solea. Paris, Gallimard. 2016 [1995/

1996/1998].

Daniel Dupuy. Fontcouverte. Sayat, De Borée. 2011 [2007].

Franck Bouysse. Grossir le ciel. Paris, Librairie Générale Française. 2017 [2015].

Julie de Lestrange. Hier encore, c'était l'été. Paris, Librairie Générale Française. 2017 [2016].

Franz-Olivier Giesbert. L'Immortel. Paris, J'ai lu. 2008 [2007].

Faïza Guène. Kiffe kiffe demain. Paris, Librairie Générale Française. 2009 [2004].

Sandrine Collette. Les Larmes noires sur la terre. Paris, Librairie Générale Française. 2018 [2017].

Franz-Olivier Giesbert. Le Lessiveur. Paris, J'ai lu. 2010 [2009].

Jean-Christophe Grangé. Lontano. Paris, Librairie Générale Française. 2017 [2015].

Michel Bussi. Maman a tort. Paris, Pocket. 2016 [2015].

Jean-Claude Izzo. Les Marins perdus. Paris, J’ai lu. 2016 [1997].

Jean-Christophe Grangé. Miserere. Paris, Librairie Générale Française. 2016 [2008].

Michel Bussi. N'oublier jamais. Paris, Pocket. 2016 [2014].

Bernard Minier. Nuit. Paris, Pocket. 2018 [2017].

Jérémie Guez. Paris la nuit. Paris, J’ai lu. 2015 [2011].

Jean-Christophe Grangé. Le Passager. Paris, Librairie Générale Française. 2017 [2011].

Franck Bouysse. Plateau. Paris, Librairie Générale Française. 2017 [2016].

Caryl Férey. Plutôt crever. Paris, Gallimard. 2017 [2002].

Hervé le Corre. Prendre les loups pour des chiens. Paris, Payot \& Rivages. 2018 [2017].

Pierre Pouchairet. La Prophétie de Langley. Marseille, Jigal. 2017.

Thierry Brun. Les Rapaces. Paris, Librairie Générale Française. 2017 [2016].

Franck Thilliez. Rêver. Paris, Pocket. 2017 [2016].

Jean-Christophe Grangé. Les Rivières pourpres. Paris, Librairie Générale Française. 2017 [1998].

Jean-Claude Izzo. Le Soleil des mourants. Paris, J'ai lu. 2016 [1999].

Olivier Norek. Surtensions. Paris, Pocket. 2017 [2016].

Michel Bussi. Le Temps est assassin. Paris, Pocket. 2017 [2016].

Michel Bussi. T'en souviens-tu, mon Anaïs? et autres nouvelles. Paris, Pocket. 2018. 
Sylvain Forge. Tension extrême. Paris, Fayard. 2017.

Olivier Norek. Territoires. Paris, Pocket. 2017 [2014].

Pierre Lemaitre. Trois jours et une vie. Paris, Librairie Générale Française. 2018 [2016].

Guillaume Musso. Un appartement à Paris. Paris, Pocket. 2018 [2017].

Philippe Georget. Les Violents de l'automne. Paris, Pocket. 2014 [2012]. 